\title{
Nitrogen Efficiency and Nutrient Absorption by a Sorghum-Oats Forage Succession
}

\author{
Rasiel Restelatto, ${ }^{1}$ Paulo Sergio Pavinato, ${ }^{2}$ Laércio Ricardo Sartor, ${ }^{1}$ \\ Suelen Maria Einsfeld, ${ }^{1}$ and Fernanda Paula Baldicera ${ }^{1}$ \\ ${ }^{1}$ Department of Animal Science, Federal Technology University of Paraná, Estrada/Boa Esperança, km 04, \\ 85660-000 Dois Vizinhos, PR, Brazil \\ ${ }^{2}$ Department of Soil Science, Luiz de Queiroz College of Agriculture, University of São Paulo, Avenida Pádua Dias 11, \\ 13418-900 Piracicaba, SP, Brazil \\ Correspondence should be addressed to Paulo Sergio Pavinato; pavinato@usp.br
}

Received 26 August 2014; Revised 24 November 2014; Accepted 25 November 2014

Academic Editor: Albino Maggio

Copyright (C) 2015 Rasiel Restelatto et al. This is an open access article distributed under the Creative Commons Attribution License, which permits unrestricted use, distribution, and reproduction in any medium, provided the original work is properly cited.

Balance between nutrient uptake by the crop and the amount of applied fertilizer is desired in a production system, and this measurement can predict the nutrient use efficiency. The present study aimed to evaluate nitrogen- (N-) use and recovery efficiency and extraction of $\mathrm{N}$, phosphorus (P), and potassium (K) by sorghum (Sorghum bicolor) and black oat (Avena strigosa) forages under nitrogen fertilization in three consecutive crop cultivation. The experiment was carried out at Federal Technological University of Paraná (UTFPR), Dois Vizinhos, Paraná, Brazil, in Rhodic Hapludox soil. Treatments included 0, 37.5, 75, 150, 225, 300, and $375 \mathrm{~kg} \mathrm{~N} \mathrm{ha}^{-1}$ applied to sorghum in the summer seasons of 2010/2011 and 2011/2012, intercalated by, respectively, 0, 40, 80, 120, 160, 200 , and $240 \mathrm{~kg} \mathrm{~N} \mathrm{ha}^{-1}$ applied to black oat in the winter/2011. Forage production, N, P, and K extraction, and N recovery efficiency were determined through samplings during the crop cycle. The highest sorghum forage production and $\mathrm{N}$ and $\mathrm{K}$ extraction were under 230 to $300 \mathrm{~kg} \mathrm{~N} \mathrm{ha}^{-1}$, which was around $190 \mathrm{~kg} \mathrm{~N} \mathrm{ha}^{-1}$ for black oat. The values of $\mathrm{N}$ recovery, efficiency, and $\mathrm{N}$-use physiological efficiency were higher under lower $\mathrm{N}$ rates for both crops. Based on this, about $150 \mathrm{~kg} \mathrm{~N}^{-1}$ is recommended to obtain good sorghum forage production with higher $\mathrm{N}$ efficiency levels, which is about $120 \mathrm{~kg} \mathrm{~N} \mathrm{ha}^{-1}$ for black oat.

\section{Introduction}

Brazilian animal grazing has a significant participation in general agricultural production, composing an expressive part of the country growth income. The efficiency of animal production in a grazing system is the main concern, being necessary enough forage to feed the animals in a sustainable way [1]. The best alternative for this is improving soil and plant management, choosing forage with high yield and high quality, maintaining soil fertility in adequate levels, and determining the maximum fertilizers use efficiency [2].

Most farmers assume that grazing production systems are self-sustaining, requiring low fertilizer inputs to resupply losses by animal extraction [3]. The continued exploitation in these systems may not be able to maintain the balance for a long period of time without fertilizer amendments. Oenema et al. [4] and Martha Júnior et al. [3] suggest that removal of nutrients through cattle grazing causes imbalance over the time, with degradation of soil reserves of nutrients.

To avoid unnecessary costs with higher amounts of fertilizers, determination of the nutrient content in plants, especially in harvested tissue, is necessary. This information would be useful to predict removal, which is essential in developing cost-effective fertilizer recommendations [5]. Following water availability, $\mathrm{N}$ is the second most limiting factor for biomass production in natural ecosystems [6]. However, the nutrient demand for plants is not sufficient in soil for long-term sustainability.

Selection of forage with high potential yield can respond effectively to managements [7]. Sorghum $\mathrm{sp}$ is characterized as $\mathrm{C}_{4}$ physiology, presenting a great forage yield with a high nutritional quality, with high carbohydrates content $[8,9]$, a great potential for ethanol [10, 11], and biodiesel use [12], and is also an effective crop for soil protection [13]. This 


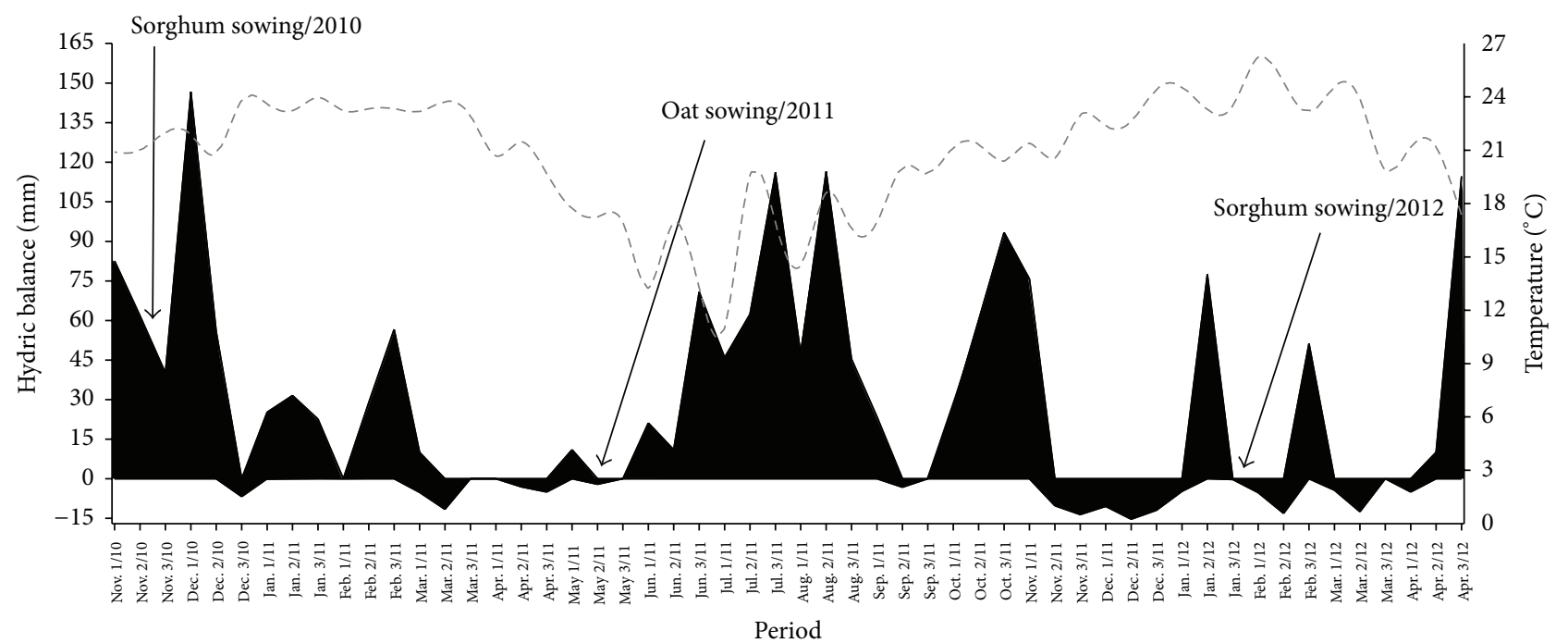

FIgURE 1: Soil water balance and mean temperatures of the experimental area during the period from November 2010 to April 2012.

TABLE 1: Chemical soil characteristics prior to sowing of sorghum in 2010.

\begin{tabular}{lccccccccrrr}
\hline $\begin{array}{l}\text { Depth } \\
(\mathrm{cm})\end{array}$ & $\begin{array}{c}\mathrm{pH} \\
\mathrm{CaCl}_{2}\end{array}$ & $\begin{array}{c}\mathrm{OM} \\
\%\end{array}$ & $\begin{array}{c}\text { P-Mehlich } \\
\mathrm{Mg} \mathrm{dm}^{-3}\end{array}$ & $\mathrm{~K}$ & $\mathrm{Ca}$ & $\mathrm{Mg}$ & $\begin{array}{c}\mathrm{Al} \\
\mathrm{cmol}_{\mathrm{c}} \mathrm{dm}^{-3}\end{array}$ & $\mathrm{H}+\mathrm{Al}$ & $\mathrm{BS}^{*}$ & $\begin{array}{c}\mathrm{CEC}^{*} \\
\mathrm{~V}^{*} \\
(\%)\end{array}$ \\
\hline $0-10$ & 4.90 & 3.48 & 8.62 & 0.30 & 5.13 & 2.34 & 0.06 & 5.35 & 7.77 & 13.12 & 59.2 \\
$10-20$ & 4.50 & 3.22 & 4.20 & 0.15 & 3.59 & 1.69 & 0.28 & 5.76 & 5.43 & 11.19 & 48.5 \\
\hline
\end{tabular}

${ }^{*}$ BS: basis sum; CEC: cation exchangeable capacity; V: basis saturation.

crop species is also tolerant to high temperatures and rainfall restricitions $[14,15]$.

The demand for cattle feeding in subtropical climates needs to be supplemented in the winter season when temperature and luminosity decrease. Including plant species adapted to the cold season in the rotation system is necessary for year-long productivity. According to Nakagawa et al. [16], black oat (Avena strigosa) is temperate and subtropical forage with high tillering, being adaptable to low temperature and low luminosity conditions, a good alternative to rotating with sorghum. This crop is capable of producing high quality forage, with high crude protein content (up to 18\%) and low fiber levels, with a potential yield of 4 to $8 \mathrm{Mg}$ of $\mathrm{DM} \mathrm{ha}^{-1}$ year $^{-1}$, an excellent alternative for cattle feeding.

The balance between the nutrient utilization and fertilizer amendment is desired in a production system. The objectives of this research were to evaluate the $\mathrm{N}$-use and recovery efficiency by sorghum and black oat and also to evaluate the exploitation of $\mathrm{N}, \mathrm{P}$, and $\mathrm{K}$ by sorghum in the summer and by black oat in the winter, under nitrogen fertilization, aiming to determine the best $\mathrm{N}$ rates for these crops' succession.

\section{Material and Methods}

2.1. Experimental Site. The study was conducted at Federal Technological University of Paraná (UTFPR), Dois Vizinhos, Paraná state, Brazil (latitude $25^{\circ} 44^{\prime}$ south, longitude $54^{\circ} 04^{\prime}$ west), with an altitude of $520 \mathrm{~m}$ above sea level. This region is characterized by a humid subtropical mesothermal climate
(Cfa) with no dry season, a mean annual rainfall of 2,100 $\mathrm{mm}$, and temperatures averaging $22^{\circ} \mathrm{C}$ in summer and $17^{\circ} \mathrm{C}$ in winter.

Rainfall and temperature data were collected during the study (INMET-SONABRA). This information was useful to estimate the climatic water balance every 10 days, following the methodology of Thornthwaite and Mather [17] and adapted by Pereira [18] (Figure 1).

Soil was Rhodic Hapludox according to soil taxonomy [19]. Chemical soil properties prior to sorghum sowing in 2010 are presented in Table 1 . The levels of available phosphorus (P) and exchangeable potassium $(\mathrm{K})$, calcium $(\mathrm{Ca})$, and magnesium $(\mathrm{Mg})$ are considered high for this soil at $0-10$ and $10-20 \mathrm{~cm}$ depth layers, with an adequate $\mathrm{pH}$ and basis saturation (V\%) for the crops tested.

2.2. Crops Used and Establishment. Crop sequence used in the experiment was sorghum-black oat-sorghum. For the summer crop seasons of 2010/2011 and 2011/2012 the sorghum $\mathrm{cv}$. Jumbo (hybrid S. bicolor $\times$ S. sudanensis) and for the winter of 2011 black oat cv. Iapar 61 (Avena strigosa) were established. The first cycle of forage sorghum was conducted during November 2010 to April 2011, with sowing date on November 11. Winter oats was also established in sequence, from May to October 2011, with sowing date on May 12. The second cycle of sorghum was conducted from January to April 2012, with sowing date on January 31. This delay in the sowing was due to lack of rain, preventing earlier crop establishment (November-December 2011) (Figure 1). 
2.3. Experimental Design and Treatments. Treatments were distributed in a completely randomized block design with three replicates. Plot size was $5 \times 5 \mathrm{~m}$, totaling $25 \mathrm{~m}^{2}$. For the two sorghum cycles, the row spacing was $40 \mathrm{~cm}$, with a density of $15 \mathrm{~kg} \mathrm{ha}^{-1}$ of viable seeds. Nitrogen rates $0,37.5$, $75,150,225,300$, and $375 \mathrm{~kg} \mathrm{~N} \mathrm{ha}^{-1}$ were distributed in three similar applications of $1 / 3$ at sowing, $1 / 3$ after the first cut, and $1 / 3$ after the third cut. The application dates for the year 2010/2011 were as follows: at sowing, November 15, 2010; after the first cut, December 29, 2010; and after the third cut, March 02, 2011. For the second year (2011/2012), dates were as follows: at sowing, January 31, 2012; after the first cut, March 02, 2012; and after the third cut, March 30, 2012.

The black oat in the winter 2011 season was sown at row spacing of $20 \mathrm{~cm}$, with a density of $40 \mathrm{~kg} \mathrm{ha}^{-1}$ of viable seeds; testing doses of $0,40,80,120,160,200$, and $240 \mathrm{~kg} \mathrm{~N} \mathrm{ha}^{-1}$ were also distributed in three applications: $1 / 3$ at tillering (June 16, 2011), 1/3 after the first cut (July 09, 2011), and 1/3 after the third cut (August 13, 2011). The amount of total $\mathrm{N}$ applied in oats was lower than sorghum since the potential DM yield of this crop is presumed lower.

2.4. Forage Production. Sampling of forage sorghum plant tissue was performed manually by cutting $0.50 \mathrm{~m}$ above ground level of two rows per plot $\left(0.40 \mathrm{~m}^{2}\right)$, when crops were 0.70 to $0.80 \mathrm{~m}$ in height. The remaining plot was also cut and removed manually, leaving a residue of about $0.20 \mathrm{~m}$ for regrowth and new sampling. Black oat forage sampling was performed when the crop reached about $0.25-0.30 \mathrm{~m}$ in height, through a manual cut to $0.10 \mathrm{~m}$ above ground level in $0.50 \mathrm{~m}$ of two rows $\left(0.20 \mathrm{~m}^{2}\right)$ per plot. The remaining plot was handled by a mechanical cutter, in the same height of the sample collected $(0.10 \mathrm{~m})$. The samples were weighted to estimate green mass yield. After that, it was dried in a forced air circulation oven at a temperature of $60^{\circ} \mathrm{C}$ for 72 hours or until constant weight to estimate dry matter, followed by laboratory analysis to estimate nutrient uptake.

2.5. Determination of Macronutrients. The concentrations of the macronutrients $\mathrm{N}, \mathrm{P}$, and $\mathrm{K}$ in the $\mathrm{DM}$ were determined according to the methodology described by Tedesco et al. [20]. After sulfuric digestion, $\mathrm{N}$ was measured at analytical method semimicro-Kjeldahl, $\mathrm{P}$ was determined by analytical method of blue-molybdate in colorimeter, and $\mathrm{K}$ was estimated by flame photometry. All multiplied by DM yield to find the total nutrients accumulated.

2.6. Nitrogen-Use Efficiency by Forage Production. The recovery of $\mathrm{N}(\mathrm{RN})$, the physiology efficiency $(\mathrm{PE})$, and the recovery efficiency of use of $\mathrm{N}$ (RAN) were calculated by the equations according to Fageria [21]. Recovery was calculated according to the following formula:

$$
\mathrm{RN}=\frac{(\mathrm{NCT}-\mathrm{NST})}{\mathrm{DN}} \times 100,
$$

where $\mathrm{RN}(\%)$ corresponds to the recovery of nitrogen; NCT corresponds to the total nitrogen absorbed with $\mathrm{N}$ application $\left(\mathrm{kg} \mathrm{ha}^{-1}\right)$; NST is total nitrogen absorbed without $\mathrm{N}$ application $\left(\mathrm{kg} \mathrm{ha}^{-1}\right)$; DN is dose of nitrogen $\left(\mathrm{kg} \mathrm{ha}^{-1}\right)$.

The physiological efficiency (PE) was obtained by dry mass production per unit of nutrient accumulated, which is calculated by the following formula:

$$
\mathrm{PE}=\frac{Y_{f}-Y_{0}}{N_{a b f}-N_{a b 0}}\left(\mathrm{~kg} \mathrm{~kg}^{-1}\right),
$$

where $Y_{f}$ is the total dry matter production in $\mathrm{kg} \mathrm{ha}^{-1}$ with fertilization; $Y_{0}$ is the total dry matter production in $\mathrm{kg} \mathrm{ha}^{-1}$ without fertilization; $N_{a b f}$ is the accumulation of nutrient under fertilization in $\mathrm{kg} \mathrm{ha}^{-1} ; N_{a b 0}$ is the accumulation of nutrient without fertilization in $\mathrm{kg} \mathrm{ha}^{-1}$.

The recovery efficiency of applied nitrogen (RAN) was the accumulated amount of nutrient per unit of nutrient applied, which is calculated using the following formula:

$$
\mathrm{RAN}=\frac{Q N_{f}-N_{0}}{Q_{f}}\left(\mathrm{~kg} \mathrm{~kg}^{-1}\right),
$$

where $Q N_{f}$ is the accumulation of nitrogen in $\mathrm{kg} \mathrm{ha}^{-1}$ with fertilization; $N_{0}$ is the accumulation of nitrogen in $\mathrm{kg} \mathrm{ha}^{-1}$ without fertilization; $Q_{f}$ is the amount of applied fertilizer in $\mathrm{kgha}^{-1}$.

All data were subjected to analysis of variance by SAS 9.2 [22] using a significance level of 0.05 . When significant, treatment effects on the measured or estimated parameters were evaluated by polynomial regression analysis, using means averaged across sampling dates within each cropping season. The peak of maximum response to $\mathrm{N}$ application of each parameter was obtained by the derivative of the quadratic adjustment.

\section{Results}

3.1. Forage Production. Forage production (MV) of sorghum was influenced significantly $(P<0.05)$ by $\mathrm{N}$ fertilization in both seasons evaluated (Figure 2). For the first year assessed (2010/2011), the highest production was obtained under application of $288 \mathrm{~kg} \mathrm{Nha}^{-1}$, with peak production of $73.84 \mathrm{Mg} \mathrm{MV} \mathrm{ha}^{-1}$ and with a quadratic response (Figure $2(a)$ ). The highest production in 2011/2012 was obtained under $267 \mathrm{~kg} \mathrm{Nha}^{-1}$, reaching a peak of $33.05 \mathrm{Mg} \mathrm{MV} \mathrm{ha}^{-1}$, also with a significant quadratic response (Figure 2(b)). The difference between years is explained by the rainfall deficit during November-December 2011 (Figure 1), which caused a sown delay of $77 \mathrm{~d}$ in second season establishment. The DM content (\%) in the forage produced by sorghum was not affected by $\mathrm{N}$ rates (Figures 2(a) and 2(b)), reaching mean values of 17.43 and $17.09 \%$ for 2010/2011 and 2011/2012, respectively.

The rate of $190 \mathrm{~kg} \mathrm{Nha}^{-1}$ was responsible for the highest black oat forage production in the winter of 2011, reaching $33.91 \mathrm{Mg} \mathrm{MV} \mathrm{ha}^{-1}$ (Figure 2(c)). It demonstrates that higher $\mathrm{N}$ rates may not be necessary in high-yielding environments, being necessary to calibrate an adequate rate for each crop 


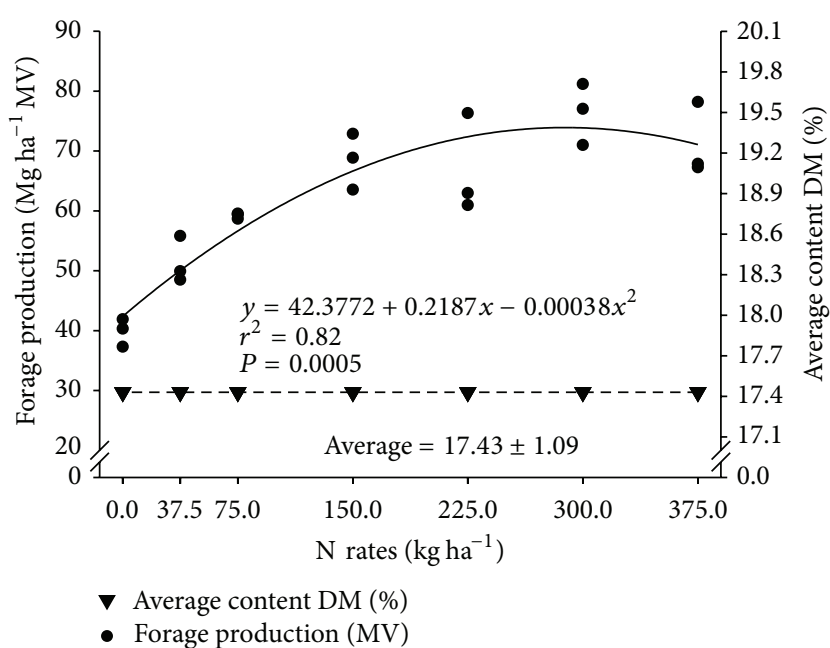

(a) Sorghum 2011

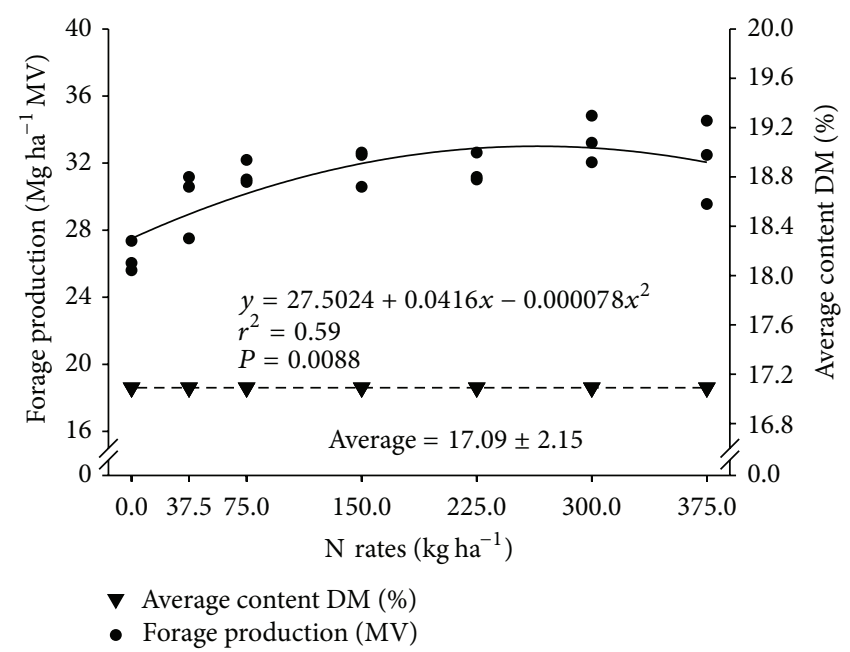

(b) Sorghum 2012

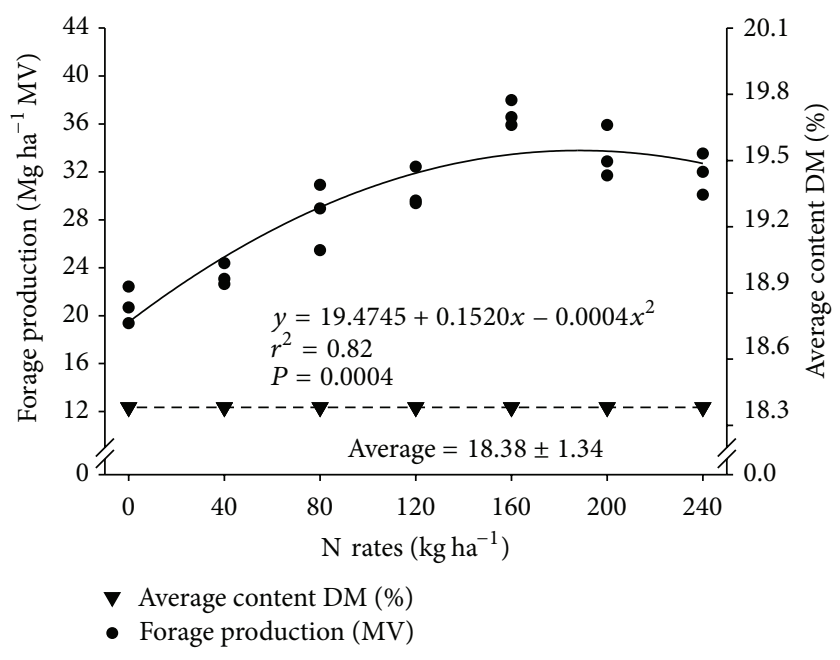

(c) Oat 2011

FIGURE 2: Cumulative production of forage $\left(\mathrm{Mg} \mathrm{ha}^{-1}\right)$ and average content of dry matter (\%) of sorghum in the summer seasons $2010 / 2011$ (a) and 2011/2012 (b) and black oat in the winter of 2011 (c), under nitrogen fertilization.

species and climate condition. Also, these rates would be even lower than the maximum output obtained in this experiment when the economic viability in the recommendation is considered. Regarding the average DM of forage produced by black oat, there was no significant effect by $\mathrm{N}$ fertilization.

\subsection{Nitrogen Extraction and Use Efficiency by Forage Produc-} tion. The amount of $\mathrm{N}$ exported through sorghum forage was affected by $\mathrm{N}$ rates applied $(P<0.05)$, for both years evaluated (Figures 3(a) and 3(b)), with a quadratic adjustment. In the crop season of 2010/2011, the highest N exportation was achieved under the rate of $298 \mathrm{~kg} \mathrm{Nha}^{-1}$, which was lower in 2011/2012, about $234 \mathrm{~kg} \mathrm{~N} \mathrm{ha}^{-1}$, reaching an export of 320 and $140 \mathrm{~kg} \mathrm{Nha}^{-1}$ each year, respectively. Comparing both seasons, exportation in 2010/2011 approached $180 \mathrm{~kg} \mathrm{~N} \mathrm{ha}^{-1}$ higher than in 2011/2012, explained by low rainfall and crop establishment delay in the second cycle, as already mentioned. For black oat, the $\mathrm{N}$ exported by forage was also adjusted to a quadratic equation (Figure 3(c)) with the largest values under $218 \mathrm{~kg} \mathrm{~N}^{-1}$.

The recovery of $\mathrm{N}$ by sorghum and black oat presented a significant effect of $\mathrm{N}$ rates $(P<0.05)$, for the three cycles evaluated (Figure 4). The N recovery by sorghum in 2010/2011 (Figure 4(a)) showed a negative linear response, reducing the amount of $\mathrm{N}$ recovered according to the increase in $\mathrm{N}$ rate. The same behavior was observed for the black oat in the winter of 2011 (Figure 4(c)). The response in $\mathrm{N}$ recovery of sorghum was quadratic in 2011/2012 season (Figure 4(b)). When comparing the crop years for sorghum, 2010/2011 presented a much higher $N$ recovery than 2011/2012, explained by the low amount of rainfall in the second year.

The physiological efficiency of $\mathrm{N}$ means the amount of $\mathrm{DM}$ produced per unit of $\mathrm{N}$ absorbed by the crop. The 


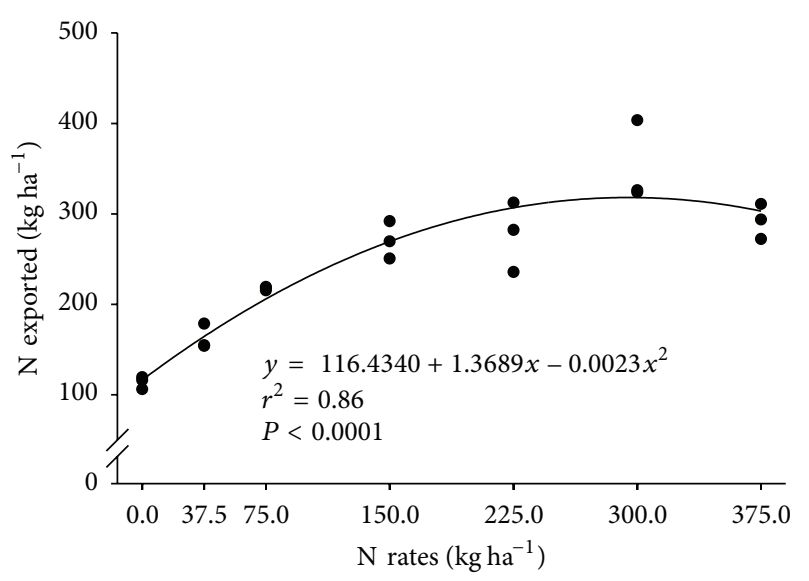

(a) Sorghum 2011

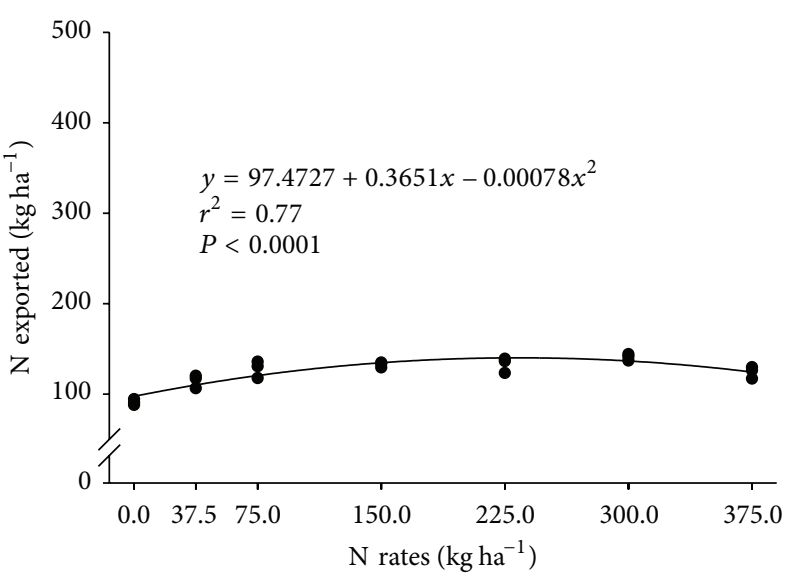

(b) Sorghum 2012

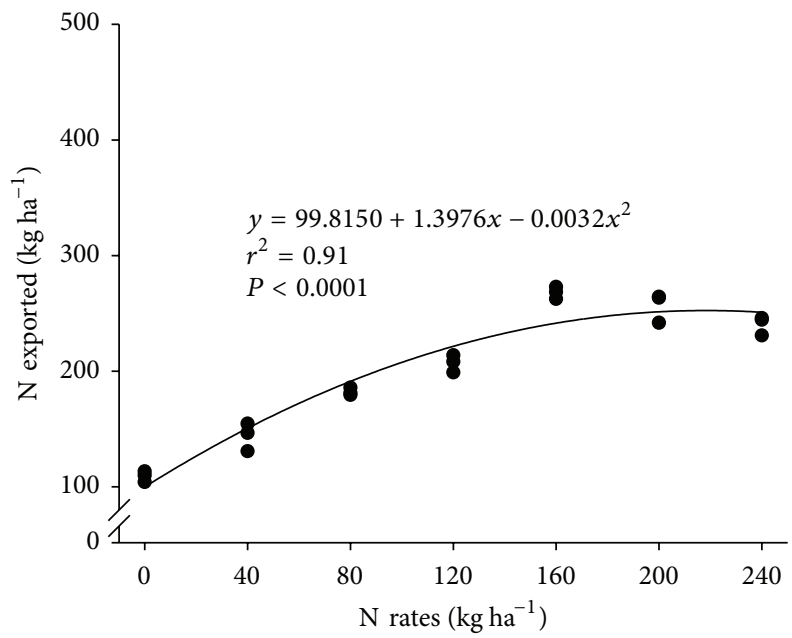

(c) Oat 2011

Figure 3: Nitrogen exported by the forage harvest of sorghum in the summer seasons of 2010/2011 (a) and 2011/2012 (b) and black oat in the winter season of 2011 (c), under nitrogen fertilization.

physiological efficiency of $\mathrm{N}$ by sorghum and oats was influenced significantly $(P<0.05)$ by $\mathrm{N}$ fertilization (Figure $5)$. For sorghum, a quadratic effect was observed, reducing the efficiency according to the increases in $\mathrm{N}$ rates (Figures 5(a) and 5(b)). The values ranged from 40, 34, 32, 29, 28, and $27 \mathrm{~kg} \mathrm{DM} \mathrm{kg}^{-1} \mathrm{~N}$ absorbed in 2010/2011 season, and 28, 20, 18 , 17,14 , and $12 \mathrm{~kg} \mathrm{DM} \mathrm{kg}^{-1} \mathrm{~N}$ absorbed in the season 2011/2012, under the rates of $37.5,75,150,225,300$, and $375 \mathrm{~kg} \mathrm{~N} \mathrm{ha}^{-1}$, respectively. For black oat, there was also a quadratic effect of applied $\mathrm{N}$ on the physiological efficiency of $\mathrm{N}$ absorbed, reaching values of $22,19,18,17,17: 16 \mathrm{~kg} \mathrm{DM} \mathrm{kg}^{-1} \mathrm{~N}$ absorbed under rates of $40,80,120,160,200$, and $240 \mathrm{~kg} \mathrm{~N}^{-1}$, respectively (Figure 5(c)). Lower $\mathrm{N}$ rates $\left(37.5\right.$ and $75 \mathrm{~kg} \mathrm{ha}^{-1}$ ) were physiologically more efficient than higher ones, for both crop species.

The nutrient use efficiency is essential for a diagnosis of the nutrient use by crops or to detect losses of this nutrient in the crop system. The efficiency of $\mathrm{N}$ recovery by sorghum in the years 2010/2011 (Figure 6(a)) and 2011/2012 (Figure 6(b)) and black oat in 2011 (Figure 6(c)) was highly influenced by $\mathrm{N}$ fertilization $(P<0.05)$. The $\mathrm{N}$ levels on recovery efficiency of sorghum presented a quadratic effect, decreasing according to $\mathrm{N}$ increases, with values ranging from 62 to $14 \mathrm{~kg} \mathrm{DM} \mathrm{kg}^{-1} \mathrm{~N}$ in the first year and 20 to $2 \mathrm{~kg} \mathrm{DM} \mathrm{kg}^{-1} \mathrm{~N}$ in the second year, under 37.5 and $375 \mathrm{~kg} \mathrm{~N} \mathrm{ha}^{-1}$, respectively. Black oat showed a linear response, with values ranging from 24 to $9 \mathrm{~kg} \mathrm{DM} \mathrm{kg}^{-1} \mathrm{~N}$ applied under 40 to $240 \mathrm{~kg} \mathrm{Nha}^{-1}$, respectively.

3.3. Phosphorus and Potassium Extraction. The amount of $\mathrm{P}$ accumulated in tissue and exported by the forage harvested is also a way to measure the effect of $\mathrm{N}$ fertilization in plant nutrient balance. Exported $\mathrm{P}$ by sorghum and black oat was directly influenced by $\mathrm{N}(P<0.05)$ (Figure 7$)$. For sorghum, the year 2010/2011 presented a quadratic response to $\mathrm{N}$ fertilization, reaching the highest $\mathrm{P}$ removal $\left(46 \mathrm{~kg} \mathrm{ha}^{-1}\right)$ under $375 \mathrm{~kg} \mathrm{~N} \mathrm{ha}^{-1}$ do not reaching the highest peak (Figure 7 (a)). Otherwise, during the year 2011/2012, the response was linear, obtaining the highest $\mathrm{P}$ exported $\left(24 \mathrm{~kg} \mathrm{ha}^{-1}\right)$ with the higher $\mathrm{N}$ rate, $375 \mathrm{~kg} \mathrm{ha}^{-1}$ (Figure $7(\mathrm{~b})$ ). Linear behavior was 


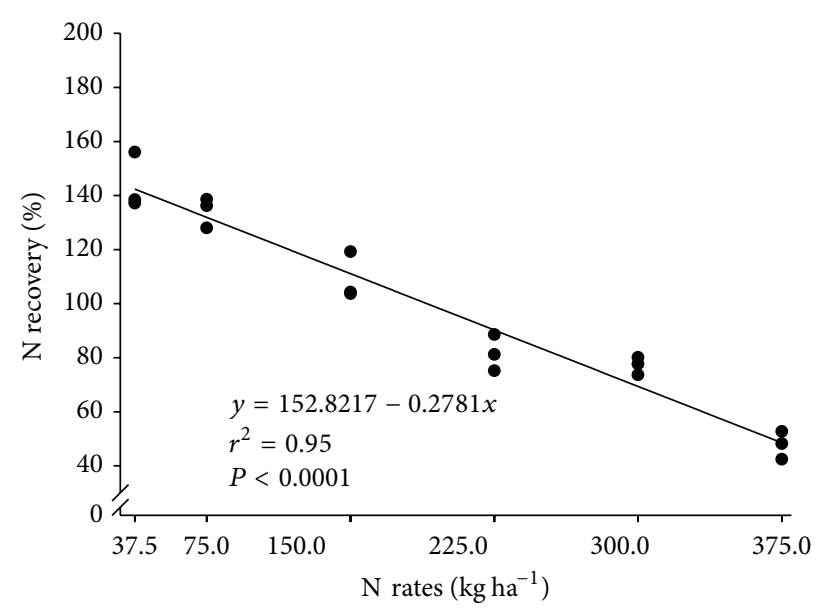

(a) Sorghum 2011

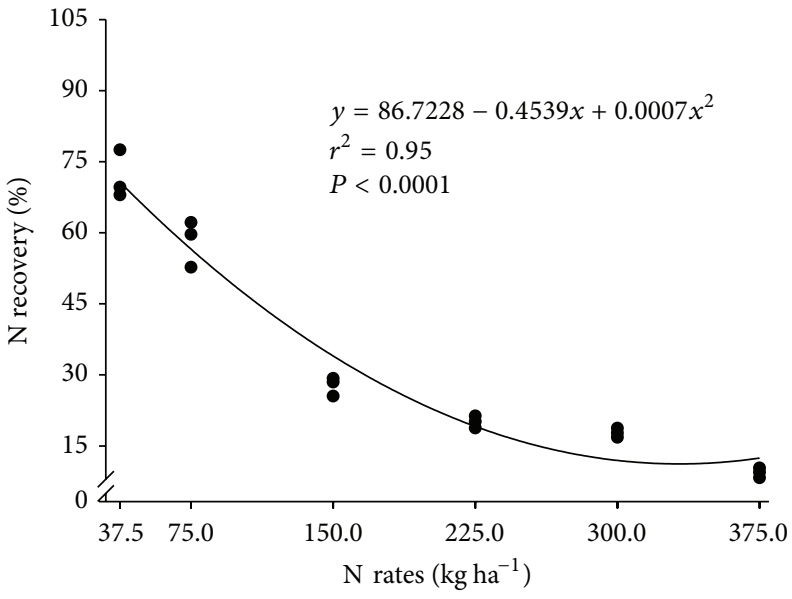

(b) Sorghum 2012

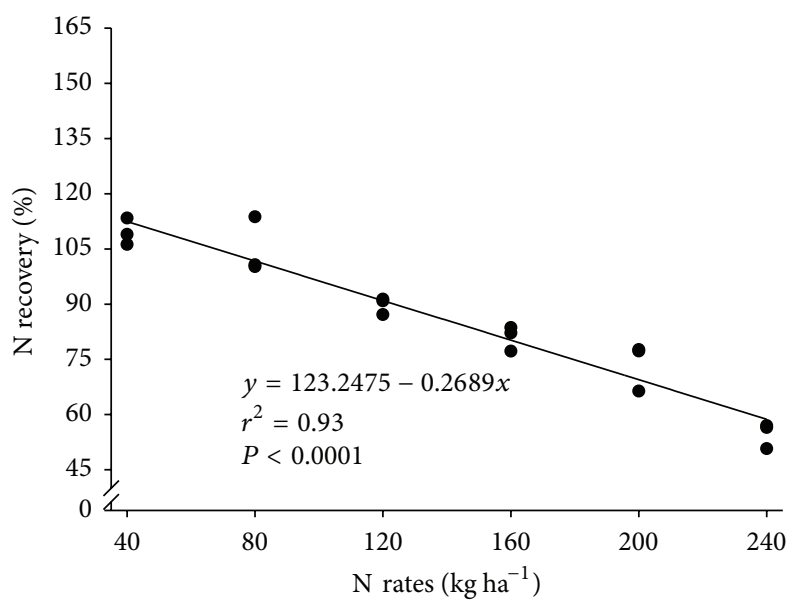

(c) Oat 2011

FiguRE 4: Nitrogen efficiency (\%) by the forage of sorghum in the summer seasons of 2010/2011 (a) and 2011/2012 (b) and black oat in the winter season of 2011 (c), under nitrogen fertilization.

also observed for black oat, with accumulated P exportation from 23 to $32 \mathrm{~kg} \mathrm{Pha}^{-1}$ under 0 to $240 \mathrm{~kg} \mathrm{~N} \mathrm{ha}^{-1}$, respectively (Figure 7(c)).

Potassium exported by annual pastures was influenced by $\mathrm{N}$ application $(P<0.05)$, since the forage production and removal are higher under fertilization. Sorghum presented a quadratic response in K exported in the year 2010/2011, reaching the peak of $\mathrm{K}$ removal $\left(180 \mathrm{~kg} \mathrm{ha}^{-1}\right)$ under the rate of $271 \mathrm{~kg} \mathrm{~N} \mathrm{ha}^{-1}$ (Figure 8(a)). Also the same behavior was observed in the year 2011/2012 but the peak of K exportation $\left(83 \mathrm{~kg} \mathrm{ha}^{-1}\right)$ was obtained under $324 \mathrm{~kg} \mathrm{~N} \mathrm{ha}^{-1}$ (Figure 8(b)). The difference of $97 \mathrm{~kg} \mathrm{~K} \mathrm{ha}^{-1}$ exported by sorghum between the years was due to lower forage production in the second season by the lack of rainfall, which was also the consequence of low crop response to $\mathrm{N}$ fertilization. For black oat, the $\mathrm{K}$ exported was also influenced by $\mathrm{N}$, as shown in Figure 8 (c), with a peak removal $\left(79 \mathrm{~kg} \mathrm{Kha}^{-1}\right)$ reaching up to $198 \mathrm{~kg} \mathrm{Nha}^{-1}$.

\section{Discussion}

Sorghum forage production (MV) in two seasons and black oat in one season were influenced by $\mathrm{N}$ fertilization, with quadratic responses observed (Figure 2). According to Heringer and Moojen [23], the quadratic response in MV is expected due to the limitations by other climatic and soil factors, since there is a certain limit in the available $\mathrm{N}$ in soil that plant can express all the productive potential. When exceeded, it causes an imbalance of other nutrients, decreasing the production and promoting unnecessary fertilizer spending.

In Brazil, there are several forage species that produce a large amount of MV. Oliveira et al. [24] observed yields of $67.18,66.48,82.00$, and $83.90 \mathrm{Mg} \mathrm{MV} \mathrm{ha}^{-1}$ of maize (Zea mays), sorghum-Sudan (Sorghum sudanensis), sorghum, and sunflower (Helianthus annuus), respectively, similar to the ones observed here for sorghum in 2010/2011. Evaluating 29 sorghum genotypes, Cunha and Lima [25] found MV ranging 


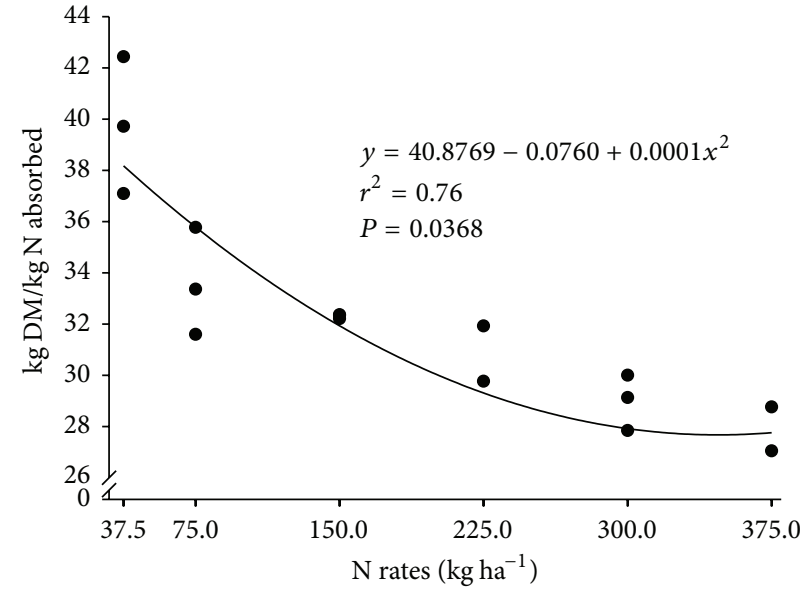

(a) Sorghum 2011

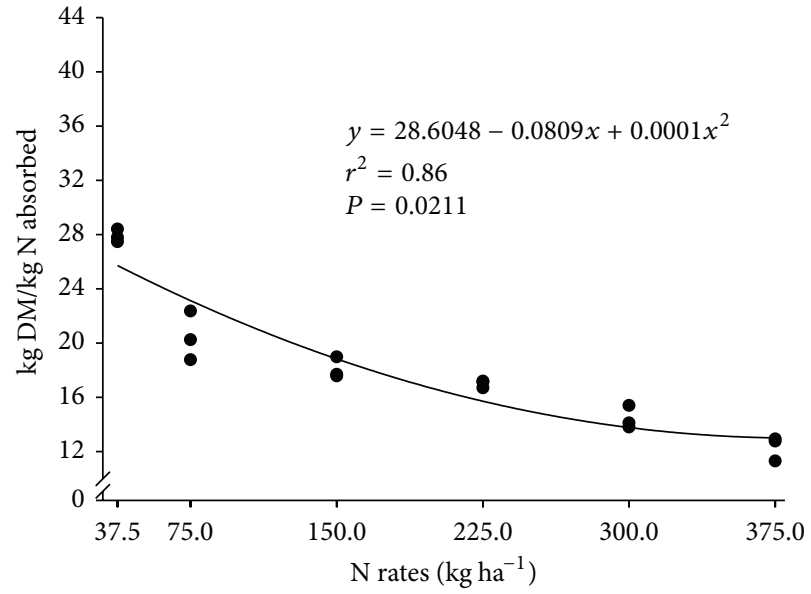

(b) Sorghum 2012

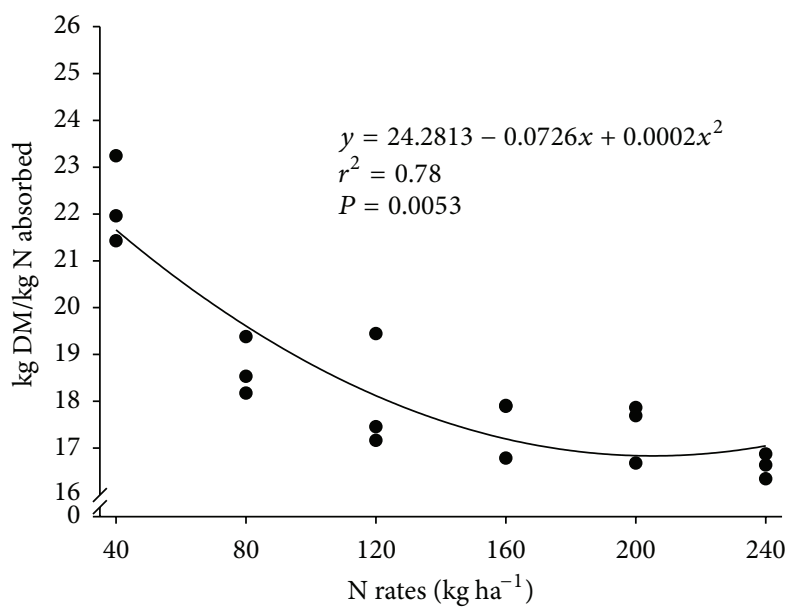

(c) Oat 2011

FIgure 5: Physiological N efficiency ( $\mathrm{kg} \mathrm{DM} \mathrm{kg}^{-1} \mathrm{~N}$ absorbed) by the forage of sorghum in the summer seasons of 2010/2011 (a) and 2011/2012 (b) and black oat in the winter season of 2011 (c), under nitrogen fertilization.

from 15.40 to $68.10 \mathrm{Mg} \mathrm{ha}^{-1}$, slightly lower than in the present work. The DM content was evaluated in sorghum-Sudan cV. AG 2501C subjected to $\mathrm{N}$ and $\mathrm{K}$ rates by Simili et al. [26] who found similar results to this study, with 17.4, 16.3, and $17.3 \%$ when under 100,200 , and $300 \mathrm{~kg} \mathrm{~N} \mathrm{ha}^{-1}$, respectively. Cunha and Lima [25] found values ranging from 17 to $33 \%$, higher than the present ones, probably as consequence of the different genotypes evaluated.

Black oat obviously presents lower potential of $\mathrm{MV}$ production than sorghum. Luz et al. [27] found yields of 18.36, 18.40, 19.49, and 18.74 $\mathrm{Mg} \mathrm{MV} \mathrm{ha}^{-1}$ under irrigation and 5.72, 5.89, 5.86, and 5.92 $\mathrm{Mg} \mathrm{MV} \mathrm{ha}^{-1}$ without irrigation, under $0,50,100$, and $150 \mathrm{~kg} \mathrm{Nha}^{-1}$, respectively, lower than those found in the present work. Results of sorghum and black oat $\mathrm{MV}$ show high response to $\mathrm{N}$ fertilization, but it is also important to consider the genotypes selection, region climate, and especially rainfall distribution. Dry matter content is not affected by $\mathrm{N}$ fertilization; however, the water availability and plant phenological stage at fodder harvest are the main factors that can influence directly this character.
The amount of $\mathrm{N}$ exported by sorghum was affected by $\mathrm{N}$ rates. There was a higher $\mathrm{N}$ accumulation in tissue in 2010/2011 (Figure 3(a)) in relation to 2011/2012 (Figure 3(b)), which can be explained by lower forage production. However, the response of the exportation in relation to $\mathrm{N}$ rates applied was quadratic for both years, meaning that crop answer to $\mathrm{N}$ fertilization is limited by other factors. Han et al. [13], evaluating five sorghum hybrids in Beijing, China, under $120 \mathrm{~kg} \mathrm{Nha}^{-1}$, found exportation of 128 and $329 \mathrm{~kg} \mathrm{Nha}^{-1}$ with early and late hybrids, respectively, corroborating the results found in the current study.

Mateus et al. [28], evaluating the MV and nutrient accumulation in shoot of Guinea sorghum (Sorghum bicolor sp. Guinea), in the crop season of 2000/2001 in São Paulo, Brazil, found an extraction from 270 to $75 \mathrm{~kg} \mathrm{~N} \mathrm{ha}^{-1}$ for early and late sowing, respectively. It was slightly lower than those found here in the first season but similar to the ones observed in the second season evaluated. It is clear that, besides $\mathrm{N}$ rates, sowing period and cultivars (early or late) have direct effect on the amount of $\mathrm{N}$ extracted, which justifies the lower $\mathrm{N}$ extraction in the second sorghum crop season $[13,28]$. 


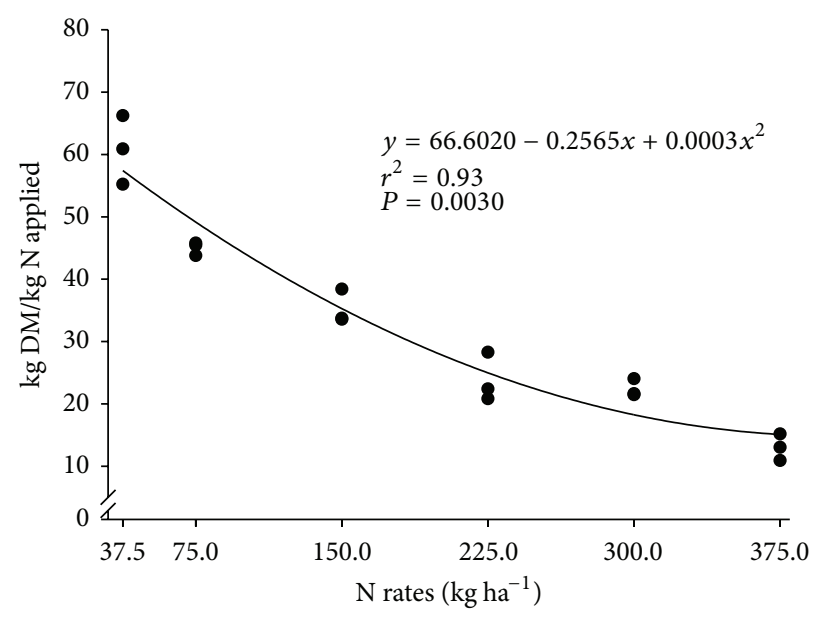

(a) Sorghum 2011

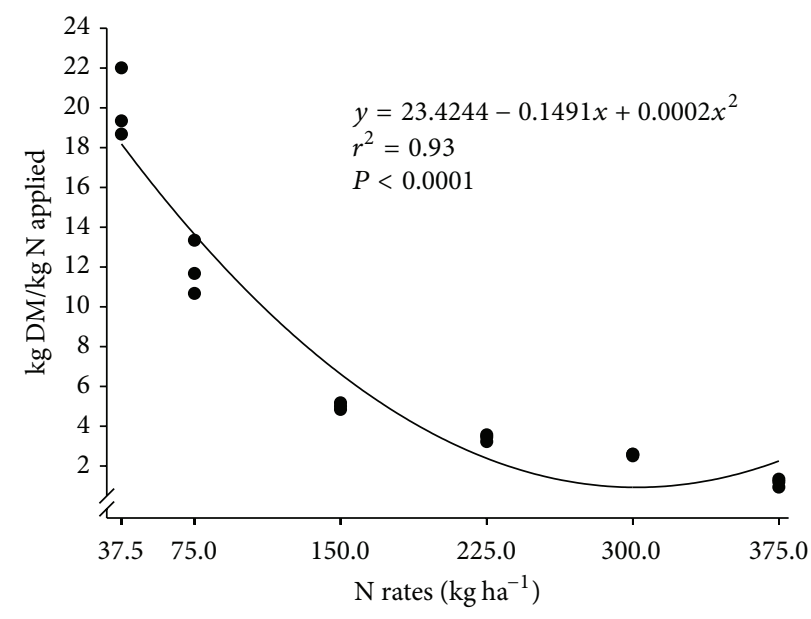

(b) Sorghum 2012

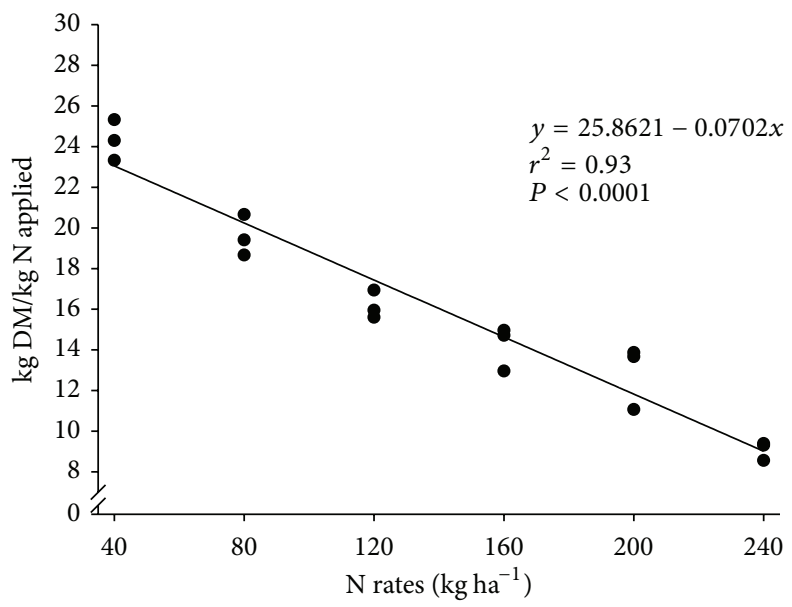

(c) Oat 2011

FIGURE 6: Nitrogen recovery efficiency ( $\mathrm{kg} \mathrm{DM} \mathrm{kg}^{-1} \mathrm{~N}$ applied) by the forage of sorghum in the summer seasons of 2010/2011 (a) and 2011/2012 (b) and black oat in the winter season of 2011 (c), under nitrogen fertilization.

Extraction of $\mathrm{N}$ by black oat was also influenced positively by $\mathrm{N}$ rates (Figure $3(\mathrm{c})$ ). The present results are higher than those normally reported in the literature, ranging from $99 \mathrm{~kg} \mathrm{Nha}^{-1}$ in control to $241 \mathrm{~kg} \mathrm{~N} \mathrm{ha}^{-1}$ under $160 \mathrm{~kg} \mathrm{ha}^{-1} \mathrm{~N}$. This difference can be explained by the cultivar planted, Iapar 61, genetically improved to assess greater vegetative cycle, produce more forage with higher feed quality, which provides a greater accumulation of $\mathrm{N}$ in tissue, ideal for regions of higher climatic potential [29].

Determining the recovery efficiency and the $\mathrm{N}$ utilization in forage production is essential to improve the system, since, in situations that the amount of $\mathrm{N}$ applied exceeds plant absorption capacity to convert into forage production, it can be lost by leaching, volatilization, or accumulating in plant tissues, reducing the DM conversion efficiency [30]. The recoveries of $\mathrm{N}$ by sorghum were higher under lower $\mathrm{N}$ rates for both years assessed, with levels ranging from 144 to $48 \%$ for the season 2010/2011 and 72 to $9 \%$ for the season 2011/2012, under 37.5 and $375 \mathrm{~kg} \mathrm{Nha}^{-1}$, respectively (Figures 4(a) and $4(\mathrm{~b})$ ).
The $\mathrm{N}$ recovery by forage may be influenced by several factors, like lack of rainfall, $\mathrm{N}$ rates, genetic potential of the crop, and crop management. Under adequate conditions of climate and soil, the recovery of $\mathrm{N}$ can exceed $100 \%$, as observed in this study (Figure 4) and in the literature. Heringer and Moojen [23], working with millet under $\mathrm{N}$ fertilization, had negative linear response to $\mathrm{N}$ recovery from $168,99,94$, and $79 \%$ when under rates of $150,300,450$, and $600 \mathrm{~kg} \mathrm{ha}^{-1}$, respectively. Also, Sartor et al. [5], working with Alexander grass (Brachiaria plantaginea), found a recovery efficiency of 110 and $49 \%$ under 200 and $400 \mathrm{~kg} \mathrm{Nha}^{-1}$, respectively. For black oat, the lowest $\mathrm{N}$ rates were the most efficient in $\mathrm{N}$ recovery (Figure $4(\mathrm{c})$ ). Under the rate $40 \mathrm{~kg} \mathrm{~N} \mathrm{ha}^{-1}$, recovery efficiency of $110 \%$ was found; however, under $240 \mathrm{~kg} \mathrm{~N} \mathrm{ha}^{-1}$, the efficiency decreased to $55 \%$. Also, Kolchinski and Schuch [31] found $\mathrm{N}$ recovery efficiency in oats ranging from 76 to $64 \%$ under rates from 20 to $80 \mathrm{~kg} \mathrm{~N} \mathrm{ha}^{-1}$, respectively, lower than those found in the present work. 


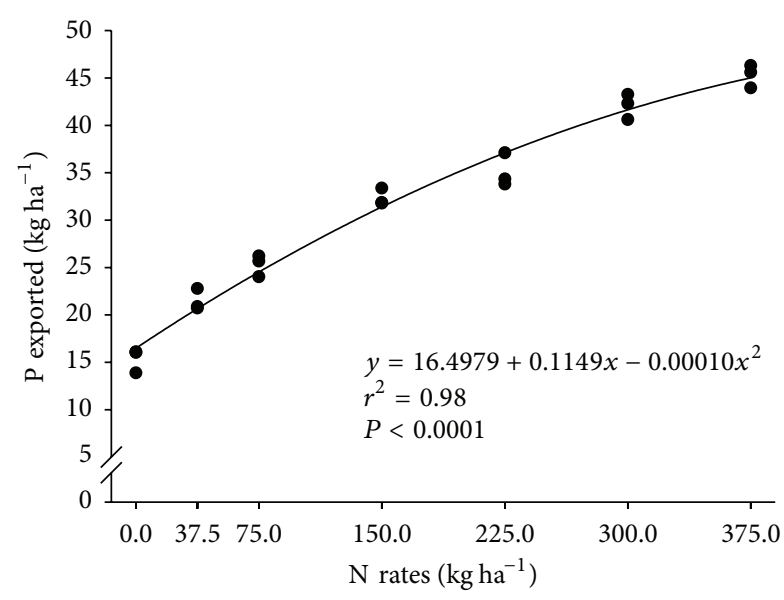

(a) Sorghum 2011

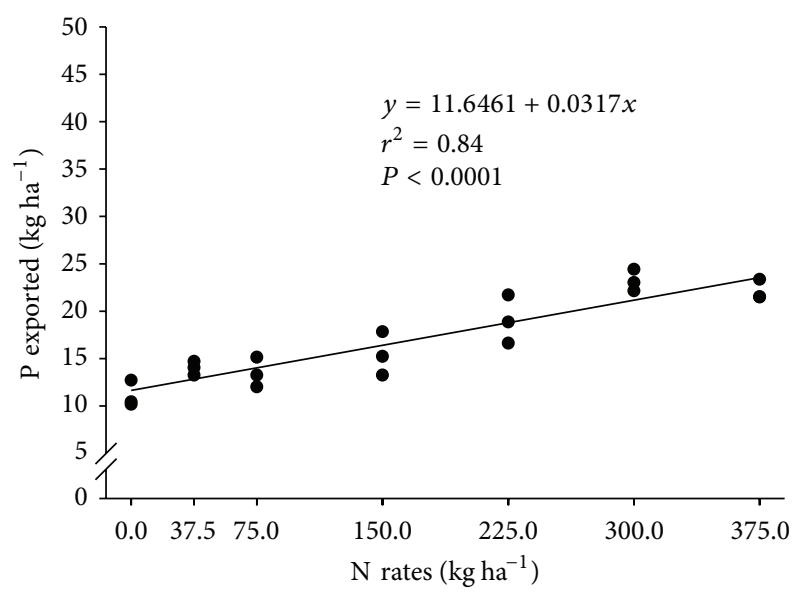

(b) Sorghum 2012

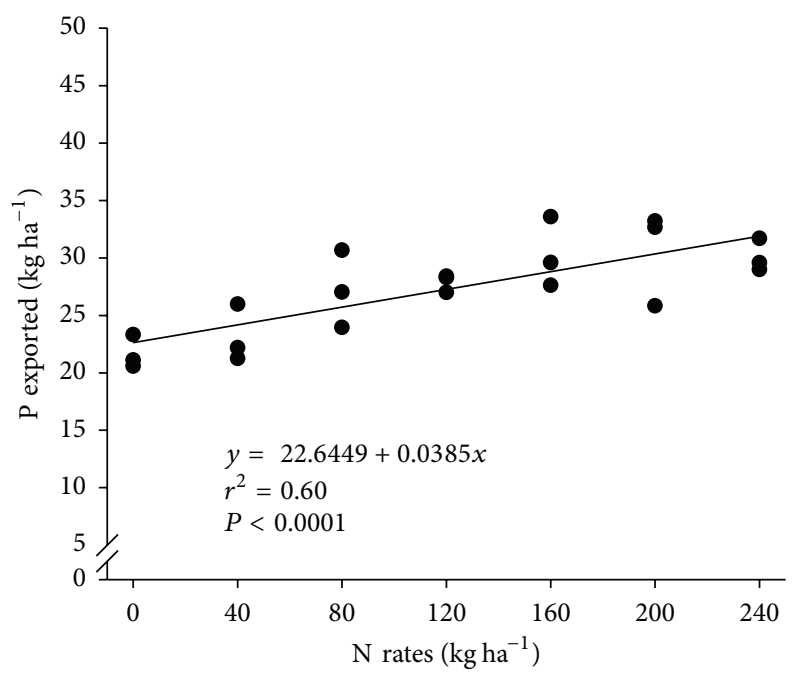

(c) Oat 2011

FIGURE 7: Phosphorus exported by the forage harvested of sorghum in the summer seasons of 2010/2011 (a) and 2011/2012 (b) and black oat in the winter season of 2011 (c), under nitrogen fertilization.

The $\mathrm{N}$ physiological efficiency by sorghum was affected by $\mathrm{N}$ fertilization (Figures 5(a) and 5(b)), obtaining the highest values, 40 and $28 \mathrm{~kg} \mathrm{DM} \mathrm{kg}^{-1} \mathrm{~N}$ absorbed for 2010/2011 and 2011/2012, respectively, when applying the lowest $\mathrm{N}$ rate, $37.5 \mathrm{~kg} \mathrm{ha}^{-1}$. Lupatini et al. [32], working with millet, found a physiological efficiency of 35 and $33 \mathrm{~kg} \mathrm{DM} \mathrm{kg}^{-1} \mathrm{~N}$ absorbed under rates of 150 and $300 \mathrm{~kg} \mathrm{ha}^{-1} \mathrm{~N}$, respectively, slightly higher than the results obtained here. Moreover, Heringer and Moojen [23] observed a progressive reduction in $\mathrm{N}$ physiological efficiency by millet, reaching values of 45 and $14 \mathrm{~kg} \mathrm{DM} \mathrm{kg}^{-1} \mathrm{~N}$ absorbed under rates of 150 and $600 \mathrm{~kg} \mathrm{Nha}^{-1}$, respectively, which was also observed here, with about $13 \mathrm{~kg} \mathrm{DM} \mathrm{kg}^{-1} \mathrm{~N}$ absorbed under the highest rate in the second season (2011/2012).

The $\mathrm{N}$ physiological efficiency of black oat was also influenced by $\mathrm{N}$ fertilization (Figure 5(c)), with values of 22 to $16 \mathrm{~kg} \mathrm{DM} \mathrm{kg}^{-1} \mathrm{~N}$ absorbed under rates of 40 and $240 \mathrm{~kg} \mathrm{Nha}^{-1}$, respectively. Lupatini et al. [33] found a physiological efficiency of 31 and $25 \mathrm{~kg} \mathrm{DM} \mathrm{kg}^{-1} \mathrm{~N}$ absorbed under rates of 150 and $300 \mathrm{~kg} \mathrm{~N} \mathrm{ha}^{-1}$, respectively, in black oat consorted to ryegrass (Lolium multiflorum Lam.), results slightly higher than the present ones. However, when $\mathrm{N}$ rates increased, physiological efficiency was reduced, as observed here and in most literature information. According to Pellegrini et al. [34], $\mathrm{N}$ fertilization may affect the production and quality of forage in ryegrass but does not alter the $\mathrm{N}$ physiological efficiency. Those authors found a physiological average efficiency of $29 \mathrm{~kg} \mathrm{DM} \mathrm{kg}^{-1} \mathrm{~N}$ absorbed under rates of 75 , 150 , and $225 \mathrm{~kg} \mathrm{~N} \mathrm{ha}^{-1}$, contradicting the results found here, which could be explained by the way the authors evaluated the fodder, simulating grazing animals; thus it is known that animals, particularly sheep used in that research, are selective, with ability to select their diet with more than $80 \%$ of leaves.

The efficiency of $\mathrm{N}$ recovery by sorghum (Figures 6(a) and 6(b)) showed quadratic and negative effect in both seasons evaluated, with maximum efficiency of 61 and 20 and minimum of 13 and $1.5 \mathrm{~kg} \mathrm{DM} \mathrm{kg}^{-1} \mathrm{~N}$ applied, under the rates of 


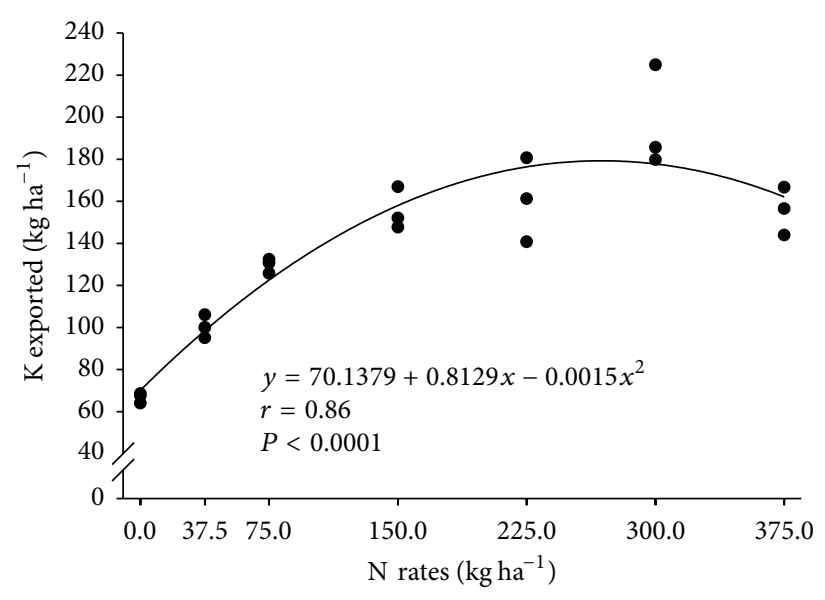

(a) Sorghum 2011

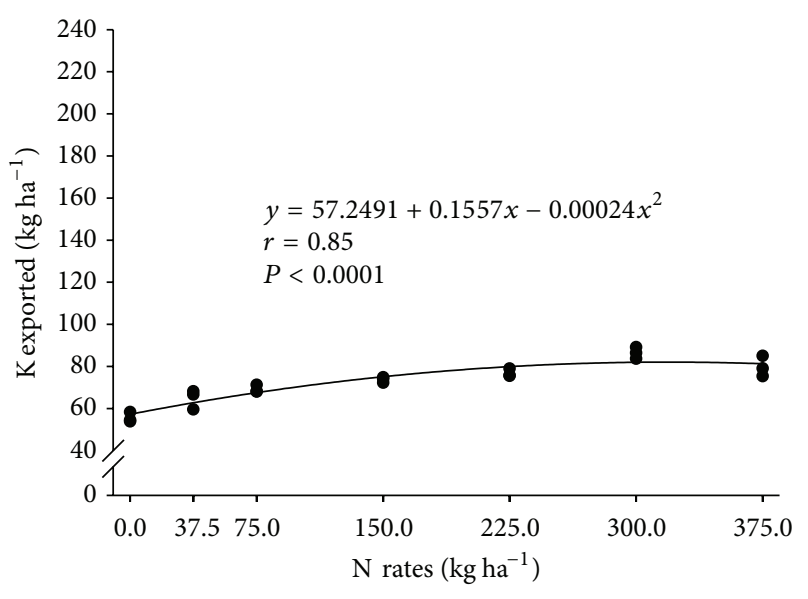

(b) Sorghum 2012

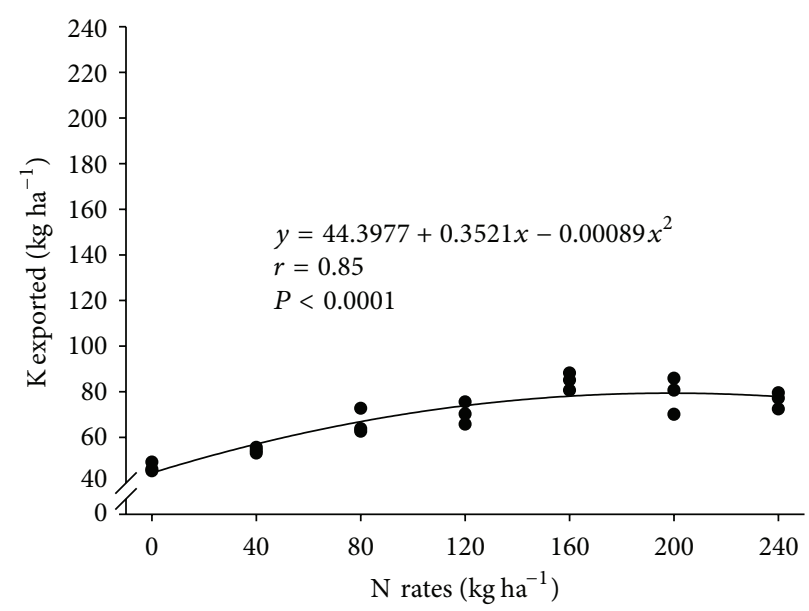

(c) Oat 2011

FIGURE 8: Potassium exported by the forage harvest of sorghum in the summer seasons of 2010/2011 (a) and 2011/2012 (b) and black oat in the winter season of 2011 (c), under nitrogen fertilization.

37.5 and $375 \mathrm{~kg} \mathrm{~N} \mathrm{ha}^{-1}$, respectively. Olanite et al. [35] found, in Nigeria, $\mathrm{N}$ recovery efficiency of 2, 9, and $6 \mathrm{~kg} \mathrm{DM} \mathrm{kg}^{-1} \mathrm{~N}$, respectively, under the rates of 60,120 , and $180 \mathrm{~kg} \mathrm{Nha}^{-1}$ in sorghum, much lower than those found here. There is huge amplitude of information in literature about efficiency of $\mathrm{N}$ recovery by sorghum, being credited to weather and soil variations, since it is known that $\mathrm{N}$ is a nutrient easily lost in soil, depending on climate changes (excess or lack of rain), fertilizer amount applied, and soil properties.

The efficiency of $\mathrm{N}$ recovery by black oat was also significantly influenced by $\mathrm{N}$ rates (Figure 6(c)), reaching a maximum of 24 and minimum of $9 \mathrm{~kg} \mathrm{DM} \mathrm{kg}^{-1} \mathrm{~N}$ under the rates of 40 and $240 \mathrm{~kg} \mathrm{ha}^{-1} \mathrm{~N}$, respectively. Moreira et al. [29] found 29,17 , and $11 \mathrm{~kg} \mathrm{DM} \mathrm{kg}^{-1} \mathrm{~N}$ applied under the rates of 50,100 , and $200 \mathrm{~kg} \mathrm{Nha}^{-1}$, respectively, corroborating the results presented here.

Phosphorus is a vital component of the plant cell and has the function of stimulating plant growth and formation of the root system in early development [36]. Among the macronutrients, phosphorus is one of the elements less absorbed by sorghum and oats. The amount of $\mathrm{P}$ exported by sorghum and oats was influenced by $\mathrm{N}$ rates (Figure 7), reaching the highest extractions in sorghum (46 and $24 \mathrm{~kg} \mathrm{Pha}^{-1}$ ) under the highest rate $\left(375 \mathrm{~kg} \mathrm{~N} \mathrm{ha}^{-1}\right)$ and lower extractions (17 and $12 \mathrm{~kg} \mathrm{ha}^{-1} \mathrm{P}$ ) without $\mathrm{N}$ fertilization, in the seasons 2010/2011 and 2011/2012, respectively. Han et al. [13] found values of P extracted ranging from 30 to $75 \mathrm{~kg} \mathrm{ha}^{-1}$ in sorghum hybrids, confirming the results found here, showing that $\mathrm{N}$ levels directly influence P extraction. Mateus et al. [28] observed that sorghum Guinea can return to the soil through biomass equivalent to $288 \mathrm{~kg} \mathrm{ha}^{-1}$ of superphosphate, concluding that sorghum is an excellent alternative to be used as cover crop.

The highest $\mathrm{P}$ extraction by black oat, $32 \mathrm{~kg} \mathrm{ha}^{-1}$, was observed under $240 \mathrm{~kg} \mathrm{Nha}^{-1}$ and reduced linearly to $23 \mathrm{~kg} \mathrm{Pha}^{-1}$ under no fertilization (Figure $7(\mathrm{c})$ ). Evaluating four pig manure rates in single oat and intercropped with vetch, Aita et al. [37] found no significant interaction between waste rate, crop species, and $\mathrm{N}, \mathrm{P}$, and $\mathrm{K}$ accumulation in shoot, with mean values of $P$ extracted of 28,27 , and $13 \mathrm{~kg} \mathrm{ha}^{-1}$ under single oat, oat consorted to vetch, and spontaneous vegetation, respectively. Moreover, the climatic conditions can greatly restrict nutrient uptake by plants. Working on a 
Brazilian Cerrado region with rainfall restrictions, Torres et al. [38] found an extraction of only $13 \mathrm{~kg} \mathrm{Pha}{ }^{-1}$ for sorghum and $4 \mathrm{~kg} \mathrm{ha}^{-1}$ for oats, much lower than those found here.

Potassium develops many important metabolic functions in plants, specially acting in enzyme activation reactions, moving freely within the plant. For sorghum, the K extracted by forage tissue was significantly influenced by $\mathrm{N}$ fertilization (Figures 8(a) and 8(b)), reaching the highest values of 180 and $83 \mathrm{~kg} \mathrm{ha}^{-1}$ under 271 and $324 \mathrm{~kg} \mathrm{Nha}^{-1}$ in the seasons 2010/2011 and 2011/2012, respectively. Oliveira et al. [24] found an amount of K extracted of 225 and $292 \mathrm{~kg} \mathrm{ha}^{-1}$ when evaluating sorghum-Sudan and common sorghum, respectively, higher than those found here. According to these authors, in crops under soil $\mathrm{K}$ deficiency, the root system will be concentrated in soil surface layers and underdeveloped, obstructing the absorption of water and nutrients. Han et al. [13] found values of 109 to $300 \mathrm{~kg} \mathrm{Kha}^{-1}$ extracted for early and mid/late sorghum hybrids, respectively. The average values obtained in this work are lower than those found in the literature, which can be explained by the early phenological stage of crop harvest, whose extraction would be lower compared to a reproductive stage harvest.

For black oat, $\mathrm{K}$ extraction was also influenced by $\mathrm{N}$ rates (Figure $8(\mathrm{c})$ ), reaching the peak of $79 \mathrm{~kg} \mathrm{~K} \mathrm{ha}^{-1}$ under $198 \mathrm{~kg} \mathrm{~N} \mathrm{ha}^{-1}$, with a quadratic behavior. According to Borkert et al. [39], oats can be a good $\mathrm{K}$ recycler, since it has a deep root system, allowing the recycling of soil $\mathrm{K}$ previously leached to subsurface layers. Giacomini et al. [40] found an extraction by black oat of 85,82 , and $74 \mathrm{~kg} \mathrm{~K} \mathrm{ha}^{-1}$, respectively, for the years 1998, 1999, and 2000. The authors emphasize that oat in crop rotation could be important to reduce $\mathrm{K}$ losses by leaching, reducing costs in fertilizer and improving gradually the soil quality for subsequent crops.

\section{Conclusions}

In general, the highest forage production of sorghum is observed under rates from 230 to $300 \mathrm{~kg} \mathrm{Nha}^{-1}$, with the highest N, P, and K extraction. For black oat cv. Iapar 61, the highest forage production is up to $190 \mathrm{~kg} \mathrm{~N} \mathrm{ha}^{-1}$.

The values of $\mathrm{N}$ recovery, recovery efficiency, and $\mathrm{N}$ use physiological efficiency are higher under lower $\mathrm{N}$ rates for both crops. Based on this, about $150 \mathrm{~kg} \mathrm{Nha}^{-1}$ is recommended to obtain good sorghum forage production with higher $\mathrm{N}$ efficiency levels, which is about $120 \mathrm{~kg} \mathrm{Nha}^{-1}$ for black oat.

\section{Conflict of Interests}

The authors declare that there is no conflict of interests regarding the publication of this paper.

\section{Acknowledgments}

Thanks are due to the Federal Technology University of Paraná (UTFPR), Dois Vizinhos, for providing the experimental area as well as the laboratory and all of the necessary material for the development and analysis of the experiment.
Thanks are due to the Program of Tutorial Education (PETZootecnia) and the Undergraduate Program of Research Fellowship of UTFPR by grants to the students of animal science, which were dedicated to complete successfully the research work. Thanks are also due to the Education Assistance Program (PAE) for master's scholarship granted during graduate study. The paper is originated from the master's dissertation of the first author.

\section{References}

[1] M. B. Dias-Filho, Desafios da produção animal em pastagens na fronteira agrícola brasileira, Embrapa Amazônia Oriental, Belém, Brazil, 2012.

[2] A. C. Primavesi, O. Primavesi, L. A. Corrêa et al., "Adubação nitrogenada em capim- coastcross : efeitos na extração de nutrientes e recuperação aparente do nitrogênio," Revista Brasileira de Zootecnia, vol. 33, no. 1, pp. 68-78, 2004.

[3] G. B. Martha Júnior, M. Corsi, P. C. O. Trivelin et al., "Perda de amônia por volatilização em pastagem de capim-tanzânia adubada com uréia no verão," Revista Brasileira de Zootecnia, vol. 33, no. 6, pp. 2240-2247, 2004.

[4] O. Oenema, H. Kros, and W. de Vries, "Approaches and uncertainties in nutrient budgets: implications for nutrient management and environmental policies," European Journal of Agronomy, vol. 20, no. 1-2, pp. 3-16, 2003.

[5] L. R. Sartor, T. S. Assmann, A. B. Soares, P. F. Adami, A. L. Assmann, and C. S. R. Pitta, "Nitrogen fertilizer use efficiency, recovery and leaching of an Alexandergrass pasture," Revista Brasileira de Ciência do Solo, vol. 35, no. 3, pp. 899-906, 2011.

[6] G. Lemaire, F. Gastal, and J. Salette, "Analysis of the effect of $\mathrm{N}$ nutrition on dry matter yield of a sward by reference to potential yield and optimum $\mathrm{N}$ content," in Proceedings of the 16th International Grassland Congress, pp. 179-180, 1989.

[7] D. C. Alves Filho, M. Neumann, J. Restle, A. N. M. Souza, and L. A. O. Peixoto, "Características agronômicas produtivas, qualidade e custo de produção de forragem em pastagem de azevém (Lolium multiflorum Lam) fertilizada com dois tipos de adubo," Ciência Rural, vol. 33, no. 1, pp. 143-149, 2003.

[8] S. Amaducci, A. Monti, and G. Venturi, "Non-structural carbohydrates and fibre components in sweet and fibre sorghum as affected by low and normal input techniques," Industrial Crops and Products, vol. 20, no. 1, pp. 111-118, 2004.

[9] Y. L. Zhao, A. Dolat, Y. Steinberger, X. Wang, A. Osman, and G. H. Xie, "Biomass yield and changes in chemical composition of sweet sorghum cultivars grown for biofuel," Field Crops Research, vol. 111, no. 1-2, pp. 55-64, 2009.

[10] D. R. Buxton, I. C. Anderson, and A. Hallam, "Performance of sweet and forage sorghum grown continuously, doublecropped with winter rye, or in rotation with soybean and maize," Agronomy Journal, vol. 91, no. 1, pp. 93-101, 1999.

[11] A. Almodares and M. R. Hadi, "Production of bioethanol from sweet sorghum: a review," African Journal of Agricultural Research, vol. 4, no. 9, pp. 772-780, 2009.

[12] C. Gao, Y. Zhai, Y. Ding, and Q. Wu, "Application of sweet sorghum for biodiesel production by heterotrophic microalga Chlorella protothecoides," Applied Energy, vol. 87, no. 3, pp. 756761, 2010.

[13] L. P. Han, Y. Steinberger, Y. L. Zhao, and G. H. Xie, "Accumulation and partitioning of nitrogen, phosphorus and potassium in 
different varieties of sweet sorghum," Field Crops Research, vol. 120, no. 2, pp. 230-240, 2011.

[14] N. Tsuchihashi and Y. Goto, "Cultivation of sweet sorghum (Sorghum bicolor (L.) moench) and determination of its harvest time to make use as the raw material for fermentation, practiced during rainy season in dry land of Indonesia," Plant Production Science, vol. 7, no. 4, pp. 442-448, 2004.

[15] C. S. Wortmann, A. J. Liska, R. B. Ferguson, D. J. Lyon, R. N. Klein, and I. Dweikat, "Dry land performance of sweet sorghum and grain crops for biofuel in Nebraska," Agronomy Journal, vol. 102, no. 1, pp. 319-326, 2010.

[16] J. Nakagawa, C. Cavariani, and J. R. Machado, "Adubação nitrogenada no perfilhamento da aveia-preta em duas condições de fertilidade do solo," Pesquisa Agropecuária Brasileira, vol. 35, no. 6, pp. 1071-1080, 2000.

[17] C. W. Thornthwaite and J. R. Mather, The Water Balance, vol. 8 of Publications in Climatology, Drexel Institute of TechnologyLaboratory of Climatology, Centerton, NJ, USA, 1955.

[18] A. R. Pereira, "Simplificado o balanço hídrico de ThornthwaiteMather," Bragantia, vol. 64, no. 2, pp. 311-313, 2005.

[19] Soil Survey Staff, Soil Taxonomy: A Basic System of Soil Classification for Making and Interpreting Soil Surveys, USDA Agricultural Handbook no. 436, Natural Resources Conservation Service, Department of Agriculture, EEUU, Washington, DC, USA, 2nd edition, 1999.

[20] M. J. Tedesco, C. Gianello, C. A. Bissani, H. Bohnen, and S. J. Volkweiss, "Análises de Solos Plantas e outros materiais," Boletim Técnico 5, Departamento de solos, Faculdade de Agronomia, Universidade Federal do Rio Grande do Sul-Porto Alegre, Porto Alegre, Brazil, 1995.

[21] N. K. Fageria, "Otimização da eficiência nutricional na produção das culturas," Revista Brasileira de Engenharia Agrícola e Ambiental, vol. 2, pp. 6-16, 1998.

[22] SAS Institute, SAS/STAT. User's Guide, version 9.2, SAS Institute Inc., Cary, NC, USA, 2008.

[23] I. Heringer and E. L. Moojen, "Potencial produtivo, alterações da estrutura e qualidade da pastagem de milheto submetida a diferentes níveis de nitrogênio," Revista Brasileira de Zootecnia, vol. 31, no. 2, pp. 875-882, 2002.

[24] L. B. de Oliveira, A. J. V. Pires, A. E. S. Viana, S. N. Matsumoto, G. G. P. deCarvalho, and L. S. O. Ribeiro, "Produtividade, composição química e características agronômicas de diferentes forrageiras," Revista Brasileira de Zootecnia, vol. 39, no. 12, pp. 2604-2610, 2010.

[25] E. E. Cunha and J. M. P. Lima, "Caracterização de genótipos e estimativa de parâmetros genéticos de características produtivas de sorgo forrageiro," Revista Brasileira de Zootecnia, vol. 39, no. 4, pp. 701-706, 2010.

[26] F. F. Simili, R. A. Reis, B. N. Furlan, C. C. P. Paz, M. L. P. Lima, and P. A. Bellingieri, "Resposta do híbrido de sorgo-sudão à adubação nitrogenada e potássica : composição química e digestibilidade in vitro da matéria orgânica," Ciência e Agrotecnologia, vol. 32, no. 2, pp. 474-480, 2008.

[27] P. H. C. Luz, V. R. Herling, G. J. Braga, J. C. M. Nogueira Filho, L. A. Faria, and C. G. Lima, "Resposta da aveia pret (Avena strigosa schreb ) à irrigação por aspersão e adubação nitrogenada," Acta Scientiarum Agronomy, vol. 30, pp. 421-426, 2008.

[28] G. P. Mateus, É. Borghi, G. S. A. Castro, R. A. Garcia, and A. C. Crusciol, "Biomass production and accumulation of nutrients in shoots of giant Guinea sorghum plants," Revista Ciencia Agronomica, vol. 42, no. 4, pp. 1000-1008, 2011.
[29] F. B. Moreira, U. Cecato, and I. N. do Prado, "Avaliação de aveia preta cv. Iapar 61 submetida a níveis crescentes de nitrogênio em área proveniente de cultura de soja," Acta Scientiarum, vol. 23, pp. 815-821, 2001.

[30] J. R. Freney, "Management practices to increase efficiency of fertilizer and animal nitrogen and minimize nitrogen loss to the atmosphere and groundwater," CSIRO Plant Industry, Australia, 2013, http://www.fftc.agnet.org/files/lib_articles/ 20130422100045/tb186.pdf.

[31] E. M. Kolchinski and L. O. B. Schuch, "Eficiência no uso do nitrogênio por cultivares de aveia branca de acordo com a adubação nitrogenada," Revista Brasileira de Ciência do Solo, vol. 27, no. 6, pp. 1033-1038, 2003.

[32] G. C. Lupatini, E. L. Moojen, J. Restle, and J. H. S. Silva, "Resposta do milheto (Pennisetum americanum (L) Leeke) sob pastejo à adubação nitrogenada," Pesquisa Agropecuária Brasileira, vol. 31, pp. 715-720, 1996.

[33] G. C. Lupatini, J. Restle, M. Ceretta, E. L. Moojen, and H. R. Bartz, "Avaliação da mistura de aveia preta e azevém sob pastejo submetida a níveis de nitrogênio," Pesquisa Agropecuária Brasileira, vol. 33, pp. 1939-1943, 1998.

[34] L. G. de Pellegrini, A. L. G. Monteiro, M. Neumann, A. de Moraes, A. C. R. S. de Pellegrin, and S. B. C. Lustosa, "Produção e qualidade de azevém-anual submetido a adubação nitrogenada sob pastejo por cordeiros," Revista Brasileira de Zootecnia, vol. 39, no. 9, pp. 1894-1904, 2010.

[35] J. A. Olanite, U. Y. Anele, O. M. Arigbede, A. O. Jolaosho, and O. S. Onifade, "Effect of plant spacing and nitrogen fertilizer levels on the growth, dry-matter yield and nutritive quality of Columbus grass (Sorghum almum stapf) in southwest Nigeria," Grass and Forage Science, vol. 65, no. 4, pp. 369-375, 2010.

[36] J. F. Karn, "Phosphorus nutrition of grazing cattle: a review," Animal Feed Science and Technology, vol. 89, pp. 133-153, 2001.

[37] C. Aita, O. Port, and S. J. Giacomini, "Dinâmica do nitrogênio no solo e produção de fitomassa por plantas de cobertura no outono /inverno com o uso de dejetos de suínos," Revista Brasileira de Ciência do Solo, vol. 30, no. 5, pp. 901-910, 2006.

[38] J. L. R. Torres, M. G. Pereira, and A. J. Fabian, "Produção de fitomassa por plantas de cobertura e mineralização de seus resíduos em plantio direto," Pesquisa Agropecuária Brasileira, vol. 43, no. 3, pp. 421-428, 2008.

[39] C. M. Borkert, C. A. Gaudêncio, J. E. Pereira, L. R. Pereira, and A. Oliveira Junior, "Nutrientes minerais na biomassa da parte aérea em culturas de cobertura de solo," Pesquisa Agropecuária Brasileira, vol. 38, no. 1, pp. 143-153, 2003.

[40] S. J. Giacomini, C. Aita, E. R. O. Vendruscolo, M. Cubilla, R. S. Nicoloso, and M. R. Fries, "Matéria seca, relação C/N e acúmulo de nitrogênio, fósforo e potássio em misturas de plantas de cobertura de solo," Revista Brasileira de Ciência do Solo, vol. 27, no. 2, pp. 325-334, 2003. 


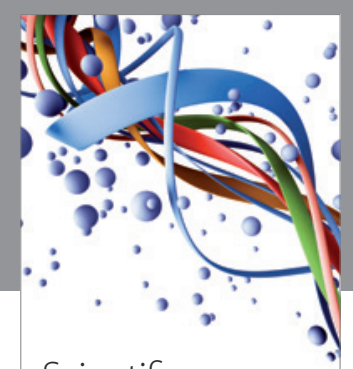

Scientifica
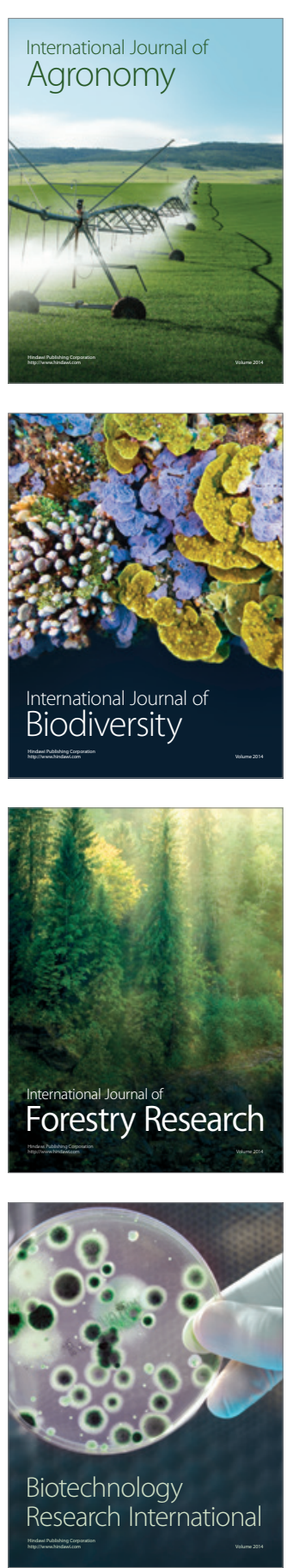
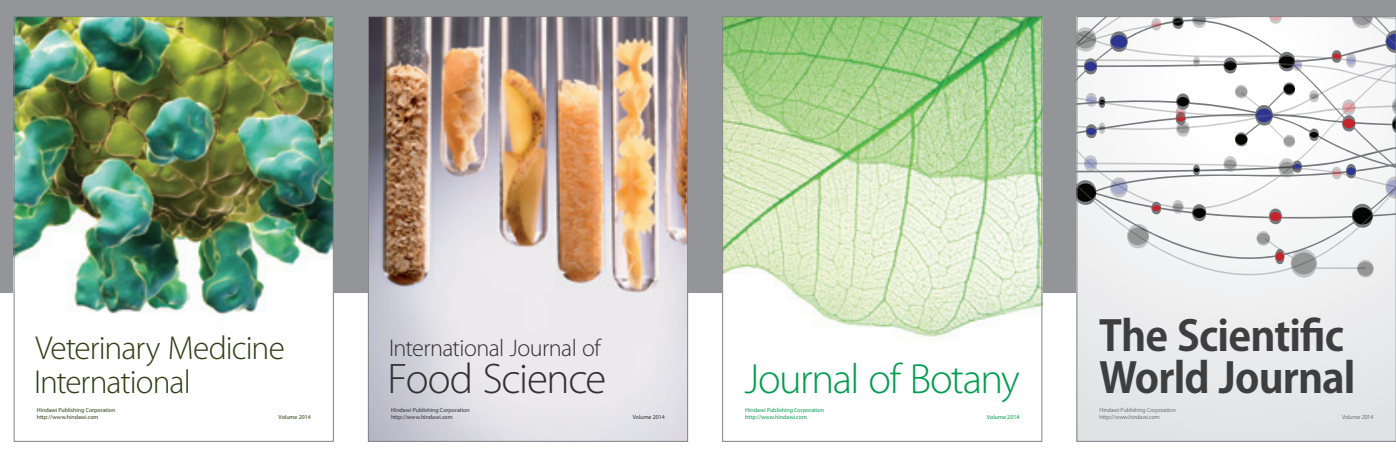

The Scientific World Journal
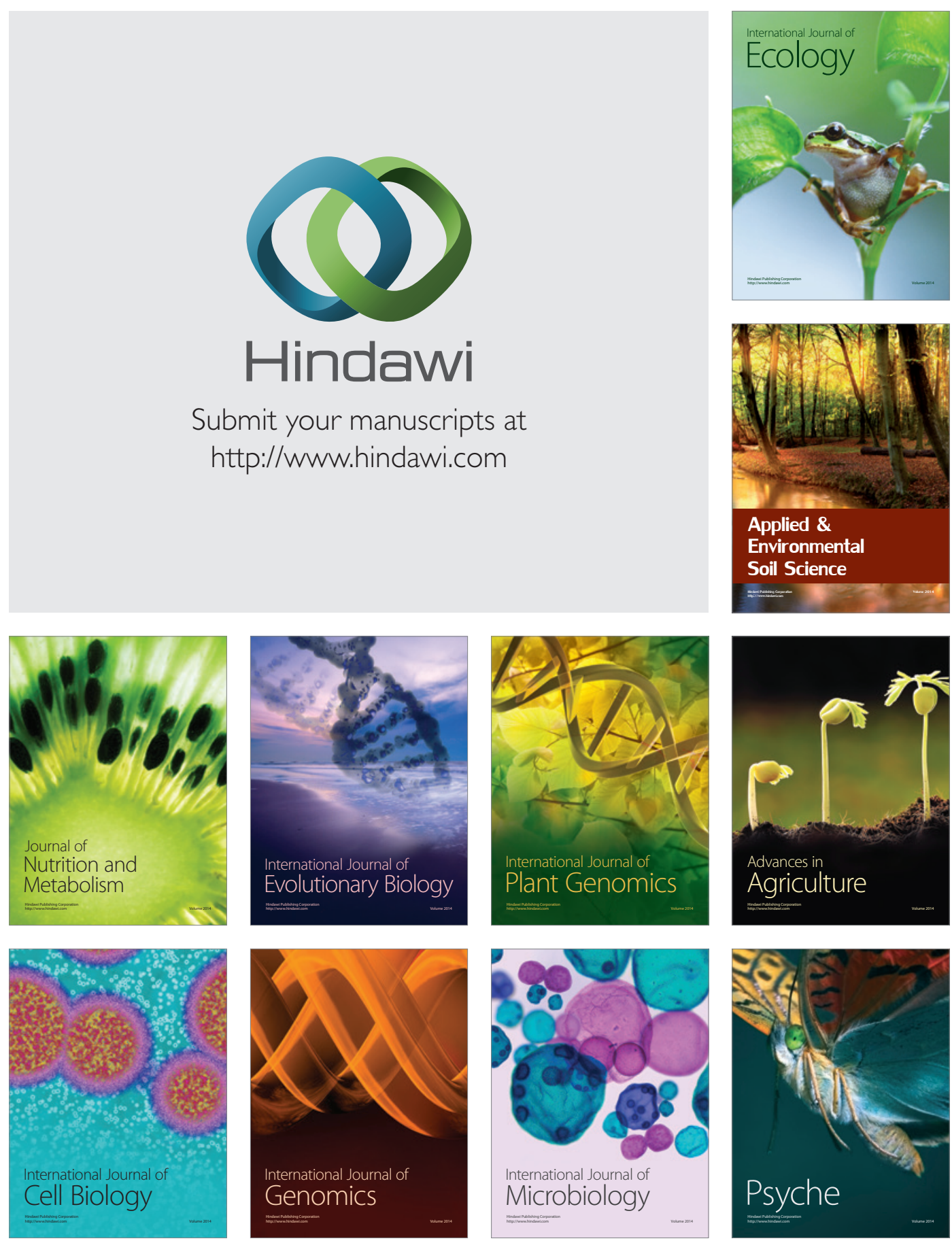